\title{
PENGEMBANGAN INSTRUMEN ASESMEN HIGHER ORDER THINGKING SKILLS (HOTS) DITINJAU DARI GAYA BELAJAR SISWA
}

\author{
Pebria Dheni Purnasari $\left(^{1}\right)$, Silvester $\mathbb{\oplus}^{2}$, dan Winda Lidia Lumbantobing $\mathbb{\oplus}^{3)}$ \\ ${ }^{1,2,3}$ Pendidikan Guru Sekolah Dasar, Instistut Shanti Bhuana \\ 1,2,3 Jl. Bukit Karmel Nomor 1, Bengkayang, 79211 \\ E-mail : pebria.dheni@shantibhuana.ac.id ${ }^{1)}$, silvester@shantibhuana.ac.id ${ }^{2}$, winda.tobing@shantibhuana.ac.id ${ }^{3)}$
}

\begin{abstract}
ABSTRAK
Tujuan dalam penelitian ini adalah untuk mengembangkan instrumen soal bertipe HOTS, serta mengidentifikasi karakteristik instrumen HOTS dan capaian HOTS berdasarkan gaya belajar siswa. Jenis penelitian ini adalah penelitian pengembangan dengan pendekatan kuantitatif deskriptif. Pengambilan data menggunakan lembar uji pakar, angket untuk mengukur gaya belajar, dan tes untuk mengukur HOTS. Analisis data menggunakan analisis deskriptif kuantitatif. Berdasarkan hasil penelitian diketahui bahwa karakteristik soal yang dikembangkan layak untuk digunakan dengan tingkat validitas dan reliabilitas yang baik. Hal ini ditunjukkan melalui hasil dari uji pakar menunjukkan bahwa instrumen asesmen yang dikembangkan dapat digunakan namun sedikit revisi. Nilai rata-rata skor yang diperoleh dari uji pakar adalah 3.38 dengan kategori baik. Hasil uji validitas melalui SPSS menunjukkan bahwa 2 soal tidak valid dan 18 soal valid, sedangkan uji reliabilitas menunjukkan skor 0.934 dengan kategori baik. Selanjutnya berdasarkan uji daya beda terdapat 18 butir soal dengan kategori baik, dan 2 butir soal dengan kategori jelek. Hasil uji tingkat kesukaran soal menunjukkan bahwa 8 soal tergolong dengan kategori mudah, 11 soal kategori sedang, dan 1 soal kategori sulit. Hasil pengukuran HOTS siswa menunjukkan bahwa $9.09 \%$ siswa berada pada kategori rendah, $72.73 \%$ siswa berada pada kategori sedang, $13.64 \%$ siswa berada pada kategori tinggi, dan $4.55 \%$ siswa berada pada kategori sangat tinggi. Hasil pengukuran gaya belajar menunjukkan bahwa terdapat 5 kategori gaya belajar siswa yakni kinestetik, auditori, visual, gabungan auditori dan kinestetik, serta gabungan visual dan kinestetik. Hampir semua siswa yang memiliki gaya belajar sesuai kategori memiliki tingkatan HOTS sedang.
\end{abstract}

Kata Kunci: Asesmen, Kemampuan Berpikir, HOTS, Gaya Belajar, Pendidikan Dasar.

\section{PENDAhUluan}

Kemampuan berpikir tingkat tinggi menjadi satu kebutuhan yang harus dipenuhi pada pendidikan di Indonesia di mana kebutuhan ini mulai merambah ke jenjang pendidikan dasar. Adanya penetapan Kurikulum 2013 pada jenjang sekolah dasar membawa perubahan dalam proses pembelajaran. Hal ini sebagaimana diungkapkan oleh (Ariesta, 2018) bahwa perkembangan Kurikulum 2013 bagi dunia pendidikan membawa paradigma baru di mana para guru sebagai pendidik diarahkan mampu menciptakan pembelajaran yang dapat meningkatkan kemampuan berpikir tingkat tinggi atau higher order thinking skills (HOTS). Ariesta menambahkan bahwa pengembangan Kurikulum 2013 sendiri berbasis pada tingkatan taksonomi Bloom hasil revisi dari Anderson di mana penekanan pada Kurikulum 2013 berfokus pada terbentuknya lulusan yang produktif, kreatif, dan inovatif. (Palobo \& Tembang, 2019) memaparkan bahwa penerapan kurikulum 2013 membawa perubahan aliran belajar ke arah constructivism, yakni peserta didiklah yang harus aktif dalam belajar. Sebelum penggunaan kurikulum 2013, kurikulum yang digunakan adalah KTSP, namun KTSP belum mampu menjawab kebutuhan perkembangan pendidikan di Indonesia. Adanya pergantian dari KTSP menjadi Kurikulum 2013 diharapkan adanya tercapainya kompetensi peserta didik agar tanggap dan terampil di abad ke-21 (Majir, 2019). Di sisi lain saat ini pemerintah juga menekankan prinsip merdeka belajar di semua jenjang. Konsep merdeka belajar ini bertujuan untuk memberikan ruang kepada siswa supaya dapat mengeksplorasi dan mengembangkan potensinya tanpa terpaku pada ruang kelas, sumber cetak pembelajaran, serta terbatasnya media pembelajaran di kelas ataupun sekolah. Hal ini tentu sejalan dengan pola pembelajaran Kurikulum 2013 yang bersasaran pada peningkatan pola berpikir. Adanya kebebasan dalam belajar juga diharapkan memberi ruang pada siswa untuk meningkatkan kemampuan berpikirnya.

Pengukuran dan pengategorian kemampuan berpikir menggunakan klasifikasi dari revisi taksonomi Bloom. Tingkatan klasifikasi dari Bloom ini memudahkan guru dalam menilai dan mengenali tahapan perkembangan siswa (Santika dkk., 2019). Revisi taksonomi Bloom yang dilakukan oleh Anderson pada kenyataannya lebih dapat digunakan oleh berbagai pihak yang berkecimpung di dunia pendidikan (Kuswana, 2014). Anderson membagi tingkat kemampuan berpikir ke dalam 2 tingkatan yakni tingkat rendah yang terdiri dari (C1) ingatan, (C2) pemahaman, dan (C3) menerapkan, serta 
tingkat tinggi yang terdiri dari analisis (C4), evaluasi (C5), kreativitas atau mencipta (C6) (Hanifah, 2019).

Untuk menjawab tantangan peningkatan HOTS, pembelajaran yang diterapkan oleh guru harus mampu mendorong tingkat kemampuan berpikir kritis dan kreatif siswa, di mana dua hal ini merupakan cakupan dari HOTS. Selain itu untuk mengukur HOTS pada siswa diperlukan instrumen yang sesuai, yakni instrumen asesmen pembelajaran atau tes berbasis HOTS. Namun, pada asesmen untuk mengukur keterampilan berpikir tingkat tinggi bagi siswa di Indonesia masih sangat terbatas bahkan dapat dikatakan kurang. (DIKDAS, 2019) menyebutkan bahwa instrumen pengukuran HOTS di Indonesia masih kurang bahkan kemampuan HOTS siswa di Indonesia seperti nalar, menganalisis, dan mengevaluasi tergolong masih lemah. Hal ini dikarenakan siswa tidak terbiasa dengan soal-soal berbasis HOTS. Di sisi lain, peran guru dalam mengembangkan instrumen HOTS sendiri juga masih pasif. Hal ini juga dikemukakan oleh (Hanifah, 2019) bahwa pada kondisi di lapangan menunjukkan bahwa kemampuan guru dalam mengelola pembelajaran untuk meningkatkan HOTS masih perlu ditingkatkan, mengingat pendidikan di Indonesia belum mengoptimalkan peningkatan HOTS. (Fitriani, Suryana, Hamdu, 2018) menyatakan bahwa kemampuan berpikir tingkat tinggi siswa dapat ditingkatkan melalui pembiasaan yang dapat diberikan dalam aktivitas belajar, di mana aktivitas belajar ini akan memberikan pengalaman bagi siswa secara khusus dalam berpikir tingkat tinggi. Salah satu upaya yang dapat dilakukan dalam meningkatkan kemampuan berpikir tingkat tinggi pada siswa adalah dengan memberikan tes atau soal-soal berbasis HOTS selain dapat mengetahui tingkat kemampuan siswa dalam menyelesaikan soal, kegiatan ini juga dapat memberikan pengalaman dan bila dilakukan secara berkesinambungan dapat membiasakan dan melatih siswa dalam berpikir tingkat tinggi (Intan, Kuntarto, Alirmansyah, 2020). Tentunya capaian kemampuan berpikir tingkat tinggi setiap siswa akan berbeda, hal ini dikarenakan siswa memiliki kecenderungan melakukan aktivitas belajar yang berbeda dengan siswa lainnya. (Ningrat dkk, 2018) menyatakan bahwa gaya belajar yang merupakan bagian dari aktivitas belajar siswa dapat menjadi salah satu penentu hasil belajar siswa. Lebih lanjut (Jampel, 2016) dalam hasil Ruang penelitiannya menyatakan bahwa gaya belajar menjadi salah satu faktor utama yang memberikan pengaruh terhadap pencapaian hasil belajar siswa. Di sisi lain (Maimunah, dkk 2020) dalam penelitiannya menunjukkan bahwa tingkatan HOTS siswa berbedabeda setelah dilakukan analisis berdasarkan gaya belajarnya. Hal serupa juga diungkapkan oleh (Partingto, $\mathrm{dkk}$, 2021) yang menunjukkan bahwa gaya belajar membuat siswa memiliki tingkatan HOTS yang berbeda.

Mengingat pentingnya kemampuan berpikir tingkat tinggi di kalangan siswa dari jenjang pendidikan sekolah dasar hingga jenjang pendidikan tinggi maka aktivitas yang dapat meningkatkan kemampuan berpikir tingkat tinggi diperlukan. Salah satu upayanya adalah dengan membiasakan siswa dalam menyelesaikan asesmen berbasis HOTS. Namun, pada kenyataannya asesmen berbasis HOTS belum membudaya termasuk pada jenjang pendidikan sekolah dasar di wilayah Bengkayang. Oleh karena itu diperlukan pengembangan instrumen asesmen HOTS secara khusus bagi siswa di jenjang sekolah dasar. Pengembangan asesmen HOTS dapat menjadi alat ukur untuk mengetahui tingkatan kemampuan berpikir tingkat tinggi. Selain itu, perlu juga dilakukan analisis terhadap gaya belajar siswa, mengingat gaya belajar siswa turut menjadi faktor dalam tingkatan kemampuan berpikir tingkat tinggi siswa. Dengan demikian hasil dari pengukuran tersebut dapat menjadi bahan evaluasi dalam perbaikan proses pembelajaran hingga mencapai sasaran peningkatan kemampuan berpikir kritis pada siswa terkhusus di jenjang sekolah dasar.

\section{RUANG LINGKUP}

Ruang lingkup dalam penelitian ini adalah untuk mengembangkan asesmen HOTS, serta menelaah karakteristik dari instrumen yang dikembangkan. Dalam hal ini berupa analisis berdasarkan uji pakar, dan uji kelayakan soal. Selain itu juga dilakukan pengkajian terhadap kedudukan gaya belajar terhadap HOTS pada siswa.

\section{BAHAN DAN METODE}

Penelitian ini merupakan penelitian pengembangan yakni dengan produk berupa asesmen HOTS pada siswa. Pendekatan dalam penelitian menggunakan kuantitatif deskriptif. Sumber data dalam penelitian ini termasuk untuk uji coba soal dan pengukuran soal bertipe HOTS adalah siswa kelas 5 di SDN 9 Bengkayang.

\subsection{Alur Penelitian}

Jenis penelitian yang digunakan adalah penelitian pengembangan dengan pendekatan kuantitatif deskriptif. Model pengembangan yang digunakan dalam penelitian ini adalah model pengembangan dari Borg and Gall. Terdapat 10 langkah dalam model pengembangan Borg and Gall (Effendi \& Hendriyani, 2016), namun untuk memudahkan pelaksanaan penelitian maka dikelompokkan menjadi tiga langkah utama. Tiga langkah dalam penelitian ini meliputi studi pendahuluan, pengembangan produk dalam hal ini instrumen asesmen, dan validasi instrumen.

Pada tahap pertama yakni studi pendahuluan, tahapan yang dilakukan adalah menganalisis kebutuhan serta mengkaji sumber-sumber data guna mendukung pengembangan instrumen. Selanjutnya, setelah data terkumpul dilakukan pembuatan draft produk yang akan dikembangkan yakni instrumen asesmen HOTS. Setelah draft produk dibuat maka draft tersebut ditelaah dan dikaji kembali sebelum diserahkan pada validator ahli untuk dinilai kelayakan produk yang dikembangkan. 
Tahap selanjutnya adalah tahap validasi. Pada tahap ini instrumen asesmen HOTS yang telah dibuat di validasi oleh ahli. Setelah dinyatakan layak, selanjutnya instrumen diuji coba skala terbatas untuk mengukur validasi dan reliabilitasnya, serta diukur tingkat kesukaran dan daya pembeda.

Setelah diperoleh kelayakan terhadap produk yang dikembangkan maka produk siap digunakan untuk mengukur pada subjek yang dituju. Dalam hal ini, asesmen diberikan untuk mengukur tingkat HOTS pada siswa kelas 5 SD. Selain pengukuran terhadap HOTS, juga dilakukan pengukuran terhadap gaya belajar siswa. Sehingga dapat diketahui tingkatan HOTS siswa berdasarkan gaya belajarnya.

\subsection{Instrumen Penelitian}

Instrumen pengumpulan data yang digunakan dalam penelitian ini adalah lembar uji pakar, test dan angket. Lembar uji pakar digunakan untuk menilai instrumen HOTS yang dikembangkan. Selanjutnya tes digunakan untuk mengukur tingkat kemampuan berpikir tingkat tinggi siswa sekolah dasar. Angket digunakan untuk mengukur gaya belajar siswa.

\subsection{Analisis Data}

Data yang diperoleh dianalisis dan diarahkan untuk menjawab pertanyaan apakah instrumen assessment yang dikembangkan sudah memenuhi kriteria valida nya, serta dapat digunakan untuk mengukur kemampuan berpikir tingkat tinggi. Valid nya perangkat pembelajaran di validasi oleh pakar serta dilakukan validasi dengan menggunakan SPSS. Adapun teknik analisis data yang digunakan dalam penelitian ini adalah sebagai berikut:

1. Analisis validasi instrumen asesmen pembelajaran

Sebelum diuji coba baik secara skala terbatas dan luas, terlebih dahulu instrumen asesmen HOTS yang dikembangkan di validasi oleh validator ahli guna melihat kelayan isi. Kriteria kelayakan perangkat ditunjukkan pada Tabel 1.

Tabel 1. Tabel Kriteria Kelayakan Instrumen Pembelajaran

\begin{tabular}{|c|l|l|}
\hline Rata-rata skor & Kriteria & \multicolumn{1}{|c|}{ Simpulan } \\
\hline $1,00<\mathrm{S}<1,60$ & $\begin{array}{l}\text { Tidak } \\
\text { baik }\end{array}$ & $\begin{array}{l}\text { Instrumen assessment } \\
\text { belum dapat digunakan dan } \\
\text { masih memerlukan } \\
\text { konsultasi }\end{array}$ \\
\hline $1,60 \leq \mathrm{S}<2,60$ & $\begin{array}{l}\text { Kurang } \\
\text { baik }\end{array}$ & $\begin{array}{l}\text { Instrumen assessment dapat } \\
\text { digunakan dengan banyak } \\
\text { revisi }\end{array}$ \\
\hline $2,60 \leq \mathrm{S}<3,60$ & Baik & $\begin{array}{l}\text { Instrumen assessment dapat } \\
\text { digunakan dengan sedikit } \\
\text { revisi }\end{array}$ \\
\hline $3,60 \leq \mathrm{S} \leq 4,00$ & $\begin{array}{l}\text { Sangat } \\
\text { baik }\end{array}$ & $\begin{array}{l}\text { Instrumen assessment dapat } \\
\text { digunakan tanpa revisi }\end{array}$ \\
\hline
\end{tabular}

Sumber: Sudjana, 2017

Rentang rata-rata skor yang ditampilkan pada Tabel 1, dihitung berdasarkan selisih nilai maximal dengan nilai minimal yang dibandingkan dengan banyaknya kriteria (Sudjana, 2017). Berdasarkan perhitungan tersebut maka dapat diperoleh nilai interval di mana nilai tertinggi adalah 4.00 dan nilai terendah adalah 1.00.

2. Analisis Butir Tes

Butir tes yang baik yakni sebelum digunakan perlu dianalisis dahulu. Analisis butir tes yang digunakan dalam penelitian ini adalah uji validitas, reliabilitas, taraf kesukaran dan daya pembeda. Dengan menggunakan instrumen yang valid dan reliabel maka diharapkan hasil penelitian valid dan reliabel. Kemudian hasil validitas dan uji reliabilitas sebagai pedoman untuk melakukan revisi terhadap butir soal.

1) Analisis validitas butir tes

Validitas yang digunakan terdiri dari validitas konstrak dan validitas isi. Untuk menguji validitas konstruk, dapat digunakan pendapat para ahli. Dalam penyusunannya instrumen dikonstruksikan sesuai dengan teori-teori yang mendukung, setelah itu dikonsultasikan dengan para ahli mengenai kelayakan instrumen yang telah dibuat apakah perlu diperbaiki atau bahkan diubah total. Untuk instrumen yang berbentuk tes, pengujian dilakukan dengan validitas isi. Validitas isi dapat dilakukan dengan membandingkan isi instrumen dengan materi pelajaran. Instrumen dikatakan memiliki validitas isi apabila mengukur khusus tertentu yang sejajar dengan materi atau isi pelajaran yang diberikan serta harus sesuai antara kompetensi dasar, indikator dan materi pelajaran.

2) Analisis Reliabilitas Tes

Uji reliabilitas dilakukan untuk mengetahui apakah soal tes yang disusun memberikan hasil yang sama meskipun tes dilakukan di lain waktu dan tempat, Reliabilitas dapat diartikan dengan sejauh mana suatu alat ukur dapat diyakini memberikan informasi yang konsisten. Suatu tes dapat dikatakan reliabel jika skor yang diperoleh dalam tes tersebut merupakan skor sesungguhnya yang menggambarkan kemampuan peserta tes.

3) Analisis tingkat kesukaran soal tes

Taraf kesukaran butir soal diperlukan untuk mengetahui apakah taraf kesukaran butir soal sudah sesuai dengan instrumen yang telah disusun. Soal yang baik adalah soal yang tidak terlalu mudah dan tidak terlalu sukar. Tingkat kesukaran soal ditunjukkan dengan bilangan yang disebut Indeks Kesukaran soal. Dengan mengetahui indeks kesukaran soal diperoleh informasi mengenai soal yang baik dan yang tidak kemudian dapat digunakan untuk mengadakan perbaikan. Taraf kesukaran dapat dihitung dengan rumus (1) (Sundayana, 2016).

Keterangan (1)

$$
\mathrm{IS}=\frac{S A+S B}{I A+I B}
$$

Is = Indeks kesukaran soal

$\mathrm{SA}=$ Jumlah skor kelompok atas

$\mathrm{SB}=$ Jumlah skor kelompok bawah

$\mathrm{IA}=$ Skor ideal kelompok atas 
IB $=$ Skor ideal kelompok bawah

Adapun kriteria yang berhubungan dengan indeks kesukaran soal ini adalah sebagai berikut:

Soal dengan $0,00 \leq \mathrm{P}<0,30$ adalah soal sukar

Soal dengan $0,30 \leq \mathrm{P} \leq 0,70$ adalah soal sedang

Soal dengan $0,70<\mathrm{P} \leq 1,00$ adalah soal mudah

(Sundayana, 2016).

4) Analisis daya beda

Daya beda soal adalah kemampuan suatu soal untuk membedakan peserta didik berkemampuan tinggi dengan peserta didik dengan kemampuan yang rendah. Angka yang menunjukkan besarnya daya pembeda disebut dengan indeks diskriminasi. Daya beda dihitung dengan rumus (2) sebagaimana dipaparkan oleh (Sundayana, 2016)

Keterangan (2)

$$
\mathrm{D}=\frac{S A-S B}{I A}
$$

$\mathrm{D}=$ Daya pembeda

$\mathrm{SA}=$ Jumlah skor kelompok atas

$\mathrm{SB}=$ Jumlah skor kelompok bawah

$\mathrm{IA}=$ Skor ideal kelompok atas

Klasifikasi terhadap daya pembeda soal ditunjukkan pada Tabel 2.

Tabel 2. Daya Beda

\begin{tabular}{|c|c|}
\hline Rentang & Kategori \\
\hline $0,00 \leq \mathrm{D}<0,20$ & Jelek \\
\hline $0,21 \leq \mathrm{D}<0,40$ & Cukup \\
\hline $0,41 \leq \mathrm{D}<0,70$ & Baik \\
\hline $0,71 \leq \mathrm{D} \leq 1,00$ & Sangat Baik \\
\hline
\end{tabular}

Sumber: Sundayana, 2016

3. Analisis HOTS dan Gaya Belajar

HOTS yang diukur melalui instrumen test selanjutnya dianalisis secara deskriptif untuk mengetahui tingkat HOTS pada siswa yang ditinjau berdasarkan gaya belajarnya. Kategori HOTS ditampilkan pada Tabel 3.

Tabel 3. Kategori HOTS

\begin{tabular}{|c|c|}
\hline Nilai & Kategori \\
\hline$<40$ & Sangat rendah \\
\hline $40-55$ & Rendah \\
\hline $56-70$ & Sedang \\
\hline $71-85$ & Tinggi \\
\hline $86-100$ & Sangat Tinggi \\
\hline
\end{tabular}

Perhitungan rentang nilai pada kategori HOTS sebagaimana disajikan pada Tabel 3 di dasarkan pada standar nilai Kriteria Ketuntasan Minimal yang telah dirancang oleh guru kelas. Selanjutnya rentang nilai tersebut digunakan untuk mengategorikan nilai HOTS siswa setelah dilakukan pengukuran.

\section{PEMBAHASAN}

Higher Order Thinking Skills atau yang sering dikenal dengan HOTS merupakan salah satu capaian dalam ranah kognitif yang dewasa ini mulai dipandang menjadi hal yang amat penting. Penerapan pembelajaran berbasis HOTS serta pengukuran tercapainya pembelajaran yang juga berbasis HOTS pada kenyataannya masih belum membudaya bagi guru. Upaya yang dapat dilakukan dalam rangka menyambut gaung HOTS dari pemerintah adalah dengan berpartisipasi aktif mengembangkan asesmen HOTS sehingga peserta didik dapat mengenal jenis-jenis soal berupa HOTS sekaligus dapat diketahui tingkatan HOTS pada siswa.

Pengembangan asesmen Higher Order Thinking Skills atau yang sering dikenal dengan HOTS dapat dikategorikan sebagai fokus pengembangan bidang pembelajaran yang ditetapkan oleh pemerintah dan mulai gencar untuk diimplementasikan dari jenjang pendidikan dasar. Namun, pada kenyataannya pengembangan HOTS baik dalam pembelajaran maupun asesmen belum terealisasi secara baik. Tidak sedikit guru yang belum terbiasa mengembangkan soal bertipe HOTS dan masih terpaku dengan buku ajar.

1. Validasi asesmen HOTS

Pengembangan asesmen HOTS dilakukan pada mata pelajaran IPA. Pengembangan soal HOTS dilakukan dengan berkonsultasi bersama guru kelas 5 SDN 9 Bengkayang sehingga cakupan materi serta tingkat kesulitan dari soal dapat sesuai dengan perkembangan peserta didik. Setelah soal disusun berdasarkan masukan dari guru maka dilakukan tahap validitas.

Validitas dilakukan dengan menyebarkan lembar uji kelayakan soal pada pakar atau ahli. Pakar dan ahli yang dipilih adalah guru, dan dosen untuk memberikan penilaian terhadap asesmen yang dikembangkan. Hasil penilaian validasi dipaparkan pada Tabel 4 .

Tabel 4. Hasil Uji Pakar

\begin{tabular}{|c|l|c|c|}
\hline No & Kode Pakar & Nilai & Kriteria \\
\hline 1 & KP_1 & 3.01 & Baik \\
\hline 2 & KP_2 & 2.98 & Baik \\
\hline 3 & KP_3 & 3.72 & Sangat Baik \\
\hline 4 & KP_4 & 3.81 & Sangat Baik \\
\hline \multicolumn{2}{|c|}{ Simpulan } & 3.38 & $\begin{array}{c}\text { Instrumen } \text { assessment } \\
\text { dapat digunakan dengan } \\
\text { sedikit revisi }\end{array}$ \\
\hline
\end{tabular}

Hasil uji pakar yang ditunjukkan pada Tabel 4 menunjukkan bahwa rata-rata nilai validasi dari ke empat pakar berada pada kategori baik dengan skor 3.38. Meskipun hasil uji pakar menunjukkan nilai yang baik, namun terdapat saran perbaikan sehingga instrumen yang dikembangkan masuk pada tahap revisi dengan bobot revisi ringan. Selanjutnya saran yang diberikan oleh pakar digunakan untuk merevisi instrumen asesmen HOTS yang dikembangkan. Uji validasi juga dilakukan dengan menyebarkan instrumen pada siswa. Selanjutnya dapat dipilah jenis soal yang valid dan yang tidak valid. Hasil dari uji validasi dipaparkan pada Tabel 5. 
Tabel 5. Uji Validasi Menggunakan SPSS

\begin{tabular}{|c|c|c|}
\hline No Soal & Nilai Validasi & Keterangan \\
\hline 1 & $.883^{* *}$ & Valid \\
\hline 2 & $.850^{* *}$ & Valid \\
\hline 3 & $.764^{* * *}$ & Valid \\
\hline 4 & $.683^{* *}$ & Valid \\
\hline 5 & $.786^{* *}$ & Valid \\
\hline 6 & $.768^{* * *}$ & Valid \\
\hline 7 & $.721^{* *}$ & Valid \\
\hline 8 & $.643^{* * *}$ & Valid \\
\hline 9 & $.682^{* * *}$ & Valid \\
\hline 10 & $.809^{* * *}$ & Valid \\
\hline 11 & $.786^{* * *}$ & Valid \\
\hline 12 & $.691^{* * *}$ & Valid \\
\hline 13 & $.641^{* * *}$ & Valid \\
\hline 14 & $.507^{* * *}$ & Valid \\
\hline 15 & $.758^{\text {*** }}$ & Valid \\
\hline 16 & 0.274 & Tidak Valid \\
\hline 17 & $.521^{* * *}$ & Valid \\
\hline 18 & $.671^{* * *}$ & Valid \\
\hline 19 & $.615^{* * *}$ & Valid \\
\hline 20 & 0.247 & Tidak Valid \\
\hline
\end{tabular}

Berdasarkan data pada Tabel 5, diketahui bahwa terdapat 2 soal yang tidak valid, selanjutnya soal yang tidak valid tersebut tidak digunakan. Selain uji validasi juga dilakukan uji reliabilitas, hasilnya adalah sebagai berikut.

Tabel 6. Hasil Uji Reliabilitas

\begin{tabular}{|c|c|c|}
\hline \multicolumn{3}{|c|}{ Reliability Statistics } \\
\hline $\begin{array}{c}\text { Cronbach's } \\
\text { Alpha }\end{array}$ & $\begin{array}{c}\text { Cronbach's Alpha Based } \\
\text { on Standardized Items }\end{array}$ & N of Items \\
\hline .935 & .934 & 20 \\
\hline
\end{tabular}

Berdasarkan data pada Tabel 6, dapat diketahui bahwa nilai reliabilitas dari instrumen yang diuji adalah 0.934. Nilai tersebut berada pada kategori sangat baik.

Berdasarkan nilai pada uji pakar, uji validitas, dan uji reliabilitas maka dapat diketahui bahwa asesmen HOTS telah berada pada kategori layak dan dapat digunakan.

2. Karakteristik asesmen HOTS

Karakteristik asesmen HOTS yang dikembangkan dinilai berdasarkan tingkat kesukaran soal, serta daya beda sehingga soal tersebut dapat dikategorikan. Uji daya beda dilakukan untuk menilai apakah soal yang dibuat dapat membedakan kemampuan siswa. Selanjutnya uji tingkat kesukaran dilakukan untuk mengetahui tingkatan dari butir soal yang dikembangkan. Pengukuran terhadap karakteristik asesmen HOTS ini diperoleh melalui tahap uji coba skala terbatas. Adapun hasil dari uji daya beda dari setiap butir soal digambarkan pada Tabel 7.
Tabel 7. Hasil Uji Daya Beda

\begin{tabular}{|c|c|c|}
\hline No Soal & Daya Beda & Keterangan \\
\hline 1 & 0.71 & Sangat Baik \\
\hline 2 & 0.48 & Baik \\
\hline 3 & 0.41 & Baik \\
\hline 4 & 0.42 & Baik \\
\hline 5 & 0.59 & Baik \\
\hline 6 & 0.42 & Baik \\
\hline 7 & 0.37 & Cukup \\
\hline 8 & 0.30 & Cukup \\
\hline 9 & 0.42 & Baik \\
\hline 10 & 0.53 & Baik \\
\hline 11 & 0.71 & Sangat Baik \\
\hline 12 & 0.41 & Baik \\
\hline 13 & 0.33 & Cukup \\
\hline 14 & 0.26 & Cukup \\
\hline 15 & 0.41 & Baik \\
\hline 16 & 0.12 & Jelek \\
\hline 17 & 0.33 & Cukup \\
\hline 18 & 0.41 & Baik \\
\hline 19 & 0.33 & Cukup \\
\hline 20 & 0.11 & Jelek \\
\hline
\end{tabular}

Hasil uji daya beda yang ditampilkan pada Tabel 7 menunjukkan bahwa rata-rata soal yang dikembangkan berada pada kategori sangat baik, hanya ada 2 soal dengan kategori daya pembeda jelek. Butir soal dengan kategori daya pembeda jelek tidak digunakan dan yang akan dipilih adalah butir soal kategori cukup, baik, dan sangat baik.

Setiap butir soal juga dianalisis tingkat kesukarannya, sehingga dapat diketahui kedudukan tiap butir soal. Hasil uji tingkat kesukaran soal ditunjukkan pada Tabel 8 .

Tabel 8. Hasil Uji Tingkat Kesukaran

\begin{tabular}{|c|c|c|}
\hline No Soal & Tingkat Kesukaran & Keterangan \\
\hline 1 & 0.64 & Sedang \\
\hline 2 & 0.69 & Sedang \\
\hline 3 & 0.64 & Sedang \\
\hline 4 & 0.69 & Sedang \\
\hline 5 & 0.69 & Sedang \\
\hline 6 & 0.69 & Sedang \\
\hline 7 & 0.69 & Sedang \\
\hline 8 & 0.84 & Mudah \\
\hline 9 & 0.82 & Mudah \\
\hline 10 & 0.69 & Sedang \\
\hline 11 & 0.67 & Sedang \\
\hline 12 & 0.76 & Mudah \\
\hline 13 & 0.89 & Mudah \\
\hline 14 & 0.65 & Sedang \\
\hline 15 & 0.87 & Mudah \\
\hline 16 & 0.95 & Mudah \\
\hline 17 & 0.82 & Mudah \\
\hline 18 & 0.89 & Mudah \\
\hline 19 & 0.27 & Sukar \\
\hline 20 & 0.63 & Sedang \\
\hline
\end{tabular}

Hasil uji tingkat kesukaran pada Tabel 8 menunjukkan bahwa sebagian besar soal berada pada tingkat kesukaran sedang dan mudah, hanya ada 1 soal 
yang berada pada kategori sukar. Selanjutnya untuk tahap pengembangan soal, akan dipilih soal dengan tingkat kategori mudah, sedang, dan sukar.

3. Tingkat HOTS Siswa Ditinjau Dari Gaya Belajar

Pengukuran tingkat HOTS siswa dilakukan pada subjek yang ditentukan dalam hal ini adalah siswa kelas 4. SDN 9 Bengkayang yang berjumlah 22 siswa

Pemilihan subjek didasarkan pada tingkat kesiapan sekolah, serta guru yang telah menerapkan HOTS dalam proses pembelajaran, sehingga dapat diukur HOTS pada siswa dengan instrumen yang telah layak. Adapun hasil pengukuran HOTS pada siswa digambarkan pada Tabel 9.

Tabel 9. Analisis HOTS Siswa

\begin{tabular}{|c|l|c|c|}
\hline No & Kode Siswa & Nilai & Kategori \\
\hline 1 & SP_1 & 61.33 & Sedang \\
\hline 2 & SP_2 & 68.00 & Sedang \\
\hline 3 & SP_3 & 44.00 & Rendah \\
\hline 4 & SP_4 & 65.33 & Sedang \\
\hline 5 & SP_5 & 70.67 & Sedang \\
\hline 6 & SP_6 & 61.33 & Sedang \\
\hline 7 & SP_7 & 90.67 & Sangat Tinggi \\
\hline 8 & SP_8 & 78.67 & Tinggi \\
\hline 9 & SP_9 & 69.33 & Sedang \\
\hline 10 & SP_10 & 54.67 & Rendah \\
\hline 11 & SP_11 & 68.00 & Sedang \\
\hline 12 & SP_12 & 66.67 & Sedang \\
\hline 13 & SP_13 & 64.00 & Sedang \\
\hline 14 & SP_14 & 80.00 & Tinggi \\
\hline 15 & SP_15 & 73.33 & Tinggi \\
\hline 16 & SP_16 & 60.00 & Sedang \\
\hline 17 & SP_17 & 62.67 & Sedang \\
\hline 18 & SP_19 & 58.67 & Sedang \\
\hline 19 & SP_20 & 56.00 & Sedang \\
\hline 20 & SP_21 & 69.33 & Sedang \\
\hline 21 & SP_22 & 58.67 & Sedang \\
\hline 22 & SP_23 & 65.33 & Sedang \\
\hline & & & \\
\hline
\end{tabular}

Pengukuran gaya belajar juga dilakukan sehingga dapat ditelaah bagaimana kemampuan HOTS pada siswa ditinjau dari gaya belajar. Hasil analisis terhadap gaya belajar ditunjukkan pada Tabel 10 .

Tabel 10. Gaya Belajar Siswa

\begin{tabular}{|c|c|}
\hline Gaya Belajar & Jumlah Siswa \\
\hline Kinestetik & 10 \\
\hline Auditori & 2 \\
\hline Visual & 1 \\
\hline Auditori \& Kinestetik & 6 \\
\hline Visual \& Kinestetik & 3 \\
\hline Total & 22 \\
\hline
\end{tabular}

Melalui Tabel 10 dapat dilihat bahwa sebagian besar gaya belajar siswa berada pada kriteria kinestetik. Tabel 10 juga menunjukkan bahwa ada 5 jenis kriteria gaya belajar siswa pada subjek yang diteliti. Persentase gaya belajar siswa ditampilkan pada Gambar 1 .

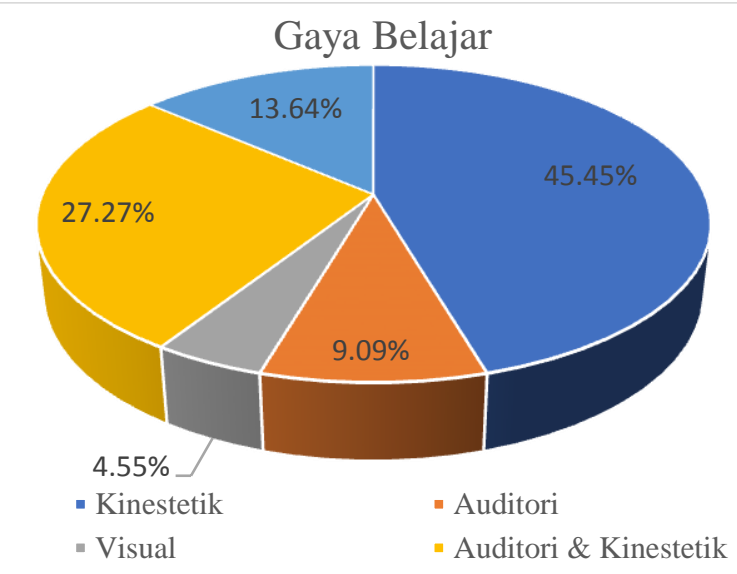

Gambar 1. Persentase Gaya Belajar Siswa

Pengembangan instrumen berupa asesmen untuk mengukur HOTS siswa dilakukan dengan tujuan mendapatkan asesmen yang layak sehingga dapat mengukur kemampuan berpikir tingkat tinggi pada siswa. Pengembangan instrumen asesmen HOTS dilakukan dengan 3 tahapan yakni pendahuluan, pengembangan instrumen dan validasi instrumen. Setelah melalui ke tiga tahapan tersebut maka dapat diketahui hasil validasi instrumen dan karakteristik dari instrumen yang dikembangkan, sehingga instrumen yang disusun dapat digunakan untuk mengukur kemampuan berpikir kritis pada siswa.

Hasil validasi instrumen baik dari uji pakar maupun uji SPSS menunjukkan bahwa sebagian besar butir soal yang terdapat dalam instrumen berada pada kategori yang layak. Hanya ada 2 butir soal yang dinyatakan tidak valid, selanjutnya 2 butir soal tersebut tidak digunakan dalam pengukuran kemampuan HOTS pada siswa. Selain uji validitas juga dilakukan uji reliabilitas di mana hasilnya menunjukkan hasil yang baik dengan skor 0.934. Uji validitas dan reliabilitas diperlukan dengan tujuan mendapatkan instrumen yang layak, terpercaya dan dapat digunakan. Hal ini sejalan dengan pendapat (Yusup, 2018) yang menyatakan bahwa uji validitas dan reliabilitas merupakan bagian penting dalam penelitian. Untuk mendapatkan data yang valid dan reliabel maka dibutuhkan instrumen yang valid dan reliabel juga, sehingga uji terhadap validitas dan reliabilitas perlu dilakukan. Hal senada juga diungkapkan oleh (Pramuaji \& Loekmono, 2018) yang menyatakan bahwa tingkat validitas yang tinggi akan menjamin keakuratan data yang diambil dalam sebuah penelitian, sehingga tahapan validitas dan reliabilitas perlu dilakukan untuk menjamin keakuratan hasil penelitian.

Karakteristik instrumen yang dikembangkan juga tergambarkan melalui uji daya beda dan tingkat kesukaran soal. Berdasarkan hasil uji daya beda maka dapat diketahui bahwa dari 20 butir soal, 2 diantaranya masuk dalam kategori sangat baik, 10 soal tergolong baik, 6 soal memiliki daya beda yang cukup, dan 2 lainnya tergolong jelek. Selanjutnya hasil uji tingkat 
kesukaran soal menunjukkan bahwa ada 1 soal dengan kategori sukar, 11 soal berada kategori sedang, dan 8 soal berada pada kategori mudah.

Berdasarkan hasil uji pakar, uji validitas, reliabilitas, daya beda, dan tingkat kesukaran maka dilakukan analisis untuk menggugurkan soal-soal yang tidak layak. Berikut ditampilkan rekapan hasil uji validitas, daya beda, dan tingkat kesukaran soal yang ditunjukkan pada Tabel 11.

Tabel 11. Rekapan Uji Validitas, Daya Beda, Tingkat Kesukaran

\begin{tabular}{|c|c|c|c|c|}
\hline $\begin{array}{c}\text { No } \\
\text { Soal }\end{array}$ & Validitas & Daya Beda & $\begin{array}{c}\text { Tingkat } \\
\text { Kesukaran }\end{array}$ & Simpulan \\
\hline 1 & Valid & Sangat Baik & Sedang & Layak \\
\hline 2 & Valid & Baik & Sedang & Layak \\
\hline 3 & Valid & Baik & Sedang & Layak \\
\hline 4 & Valid & Baik & Sedang & Layak \\
\hline 5 & Valid & Baik & Sedang & Layak \\
\hline 6 & Valid & Baik & Sedang & Layak \\
\hline 7 & Valid & Cukup & Sedang & Layak \\
\hline 8 & Valid & Cukup & Mudah & Layak \\
\hline 9 & Valid & Baik & Mudah & Layak \\
\hline 10 & Valid & Baik & Sedang & Layak \\
\hline 11 & Valid & Sangat Baik & Sedang & Layak \\
\hline 12 & Valid & Baik & Mudah & Layak \\
\hline 13 & Valid & Cukup & Mudah & Layak \\
\hline 14 & Valid & Cukup & Sedang & Layak \\
\hline 15 & Valid & Baik & Mudah & Layak \\
\hline 16 & Tidak Valid & Jelek & Mudah & Tidak Layak \\
\hline 17 & Valid & Cukup & Mudah & Layak \\
\hline 18 & Valid & Baik & Mudah & Layak \\
\hline 19 & Valid & Cukup & Sukar & Layak \\
\hline 20 & Tidak Valid & Jelek & Sedang & Tidak Layak \\
\hline & & & \multicolumn{2}{|c}{} \\
\hline
\end{tabular}

Hasil simpulan yang ditampilkan pada Tabel 11 menunjukkan bahwa terdapat 2 soal yang tidak layak yakni butir nomor 16 dan butir nomor 20 di mana ke dua butir tersebut tidak digunakan. Namun, meskipun soal yang layak ada 18 butir, yang akan digunakan dalam pengukuran HOTS hanya 15 butir saja. Pemilihan butir soal diutamakan pada aspek daya beda dengan kategori sangat baik dan baik yakni butir nomor 1, 2, 3, 4, 5, 6, 9, $10,11,12,15,18$ (12 butir soal). Selanjutnya 3 butir soal lainnya diambil berdasarkan kriteria tingkat kesukaran yang sulit (butir nomor 19), dan tingkat kesukaran dengan kategori yang mudah 2 butir yakni butir nomor 8 dan nomor 13. Dengan demikian terdapat 6 soal kategori mudah, 8 soal kategori sedang, dan 1 soal kategori mudah. Penetapan soal dibuat agar dapat memenuhi proporsi dari masing-masing kategori, di mana dalam pembuatan instrumen terdapat soal dengan tingkat kesukaran sedang, mudah, dan sukar. Oleh karena itu, mengetahui seberapa besar tingkat kesukaran soal dalam sebuah asesmen perlu dilakukan. (Yani, dkk, 2014) mengemukakan bahwa tingkat kesukaran soal merupakan acuan yang dapat digunakan untuk mengkategorikan kesukaran sebuah soal. Lebih lanjut (Bagiyono, 2017) mengemukakan bahwa uji tingkat kesukaran soal dilakukan guna mengkaji bagaimana level soal yang dibuat yang ditinjau dari kemampuan siswa bukan dari segi pengajar.

Uji kelayakan terhadap soal juga dilakukan dengan uji daya pembeda, tujuannya adalah mengidentifikasi apakah soal yang dibuat dapat membedakan kemampuan siswa dalam menyelesaikan soal. Hal ini sebagaimana diungkapkan oleh (Magdalena dkk, 2021) bahwa manfaat terhadap uji daya pembeda adalah memastikan mutu setiap butir soal dalam membedakan siswa yang telah memahami atau belum memahami materi ajar. Hal serupa juga disebutkan oleh (Yani et al., 2014) merupakan bagaimana kualitas soal dalam membedakan siswa yang memiliki kompetensi tinggi dengan kompetensi rendah. Oleh sebab itu uji daya beda perlu dilakukan untuk mendapatkan kriteria soal yang secara konteks memiliki bobot yang baik.

Setelah diperoleh kriteria soal yang layak, maka instrumen dapat digunakan untuk mengukur HOTS pada siswa kelas 5 di SDN 9 Bengkayang. Pengukuran HOTS ini bertujuan untuk mengetahui tingkat ataupun level HOTS dari masing-masing siswa di kelas tersebut sekaligus untuk membiasakan siswa dalam menyelesaikan soal bertipe HOTS. Hal ini bertujuan supaya siswa mampu memecahkan masalah yang kontekstual, mampu menyesuaikan diri dengan perubahan, serta mampu membuat keputusan dalam pemecahan masalah (Retnawati dkk, 2018). Berdasarkan pengukuran HOTS siswa maka didapatkan hasil yang menunjukkan kemampuan HOTS pada siswa. Persentase kemampuan HOTS siswa ditampilkan pada Gambar 2.

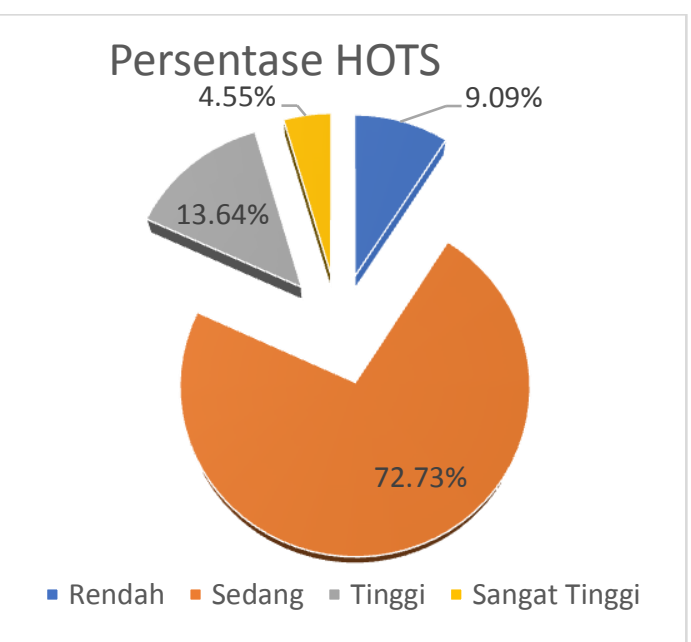

Gambar 2. Persentase HOTS Siswa

Gambar 2 menunjukkan persentase tingkat HOTS siswa, dapat diketahui bahwa rata-rata kemampuan HOTS siswa berada pada kategori sedang dengan persentase sebesar $65.57 \%$ atau sebanyak 16 siswa dari 22 siswa berada pada kategori sedang. Persentase terkecil berada pada kategori HOTS sangat tinggi yakni $4.55 \%$ atau sebanyak 1 siswa dari 22 siswa. Hasil ini menunjukkan bahwa kemampuan HOTS siswa masih 
perlu ditingkatkan lagi karena kemampuan rata-rata siswa masih dalam kategori sedang, dan masih sebagian kecil siswa yang masuk dalam kategori tinggi dan sangat tinggi. Pencapaian ini menunjukkan bahwa secara garis besar kemampuan HOTS siswa berada pada level yang cukup baik karena sebagian besar kemampuan HOTS siswa berada pada level sedang. Kemampuan HOTS ini menunjukkan bahwa siswa memiliki kompetensi dalam peningkatan keterampilan menganalisis hingga mencipta. Hal ini sebagaimana diungkapkan oleh (Sopiani, dkk, 2019) bahwa kompetensi HOTS dapat terlihat pada capaian kompetensi siswa yang berupa penguasaan konsep, metakognitis, menganalisis, mengevaluasi, dan bahkan sampai tahap mencipta.

Selain pengukuran mengenai HOTS siswa juga diukur gaya belajar siswa dan ditinjau mengenai bagaimana keterkaitan gaya belajar siswa dengan HOTS. Berdasarkan hasil pengukuran diketahui bahwa sebagian besar siswa yakni $45.45 \%$ siswa berada pada kategori gaya belajar kinestetik. Untuk mengetahui bagaimana tipe gaya belajar siswa terhadap HOTS maka dilakukan peninjauan terhadap capaian HOTS dengan karakteristik gaya belajar. Adapun hasil dari peninjauan tersebut ditunjukkan pada Tabel 12.

Tabel 12. Kategori HOTS Siswa Ditinjau Dari Gaya Belajar Siswa

\begin{tabular}{|c|c|c|c|c|c|}
\hline \multirow{2}{*}{$\begin{array}{c}\text { Gaya } \\
\text { Belajar }\end{array}$} & \multicolumn{5}{|c|}{ HOTS } \\
\cline { 2 - 6 } & $\begin{array}{c}\text { Sangat } \\
\text { Tinggi }\end{array}$ & Tinggi & Sedang & Rendah & $\begin{array}{c}\text { Sangat } \\
\text { Rendah }\end{array}$ \\
\hline Kinestetik & 0 & 2 & 7 & 1 & 0 \\
\hline Auditori & 0 & 0 & 2 & 0 & 0 \\
\hline Visual & 0 & 0 & 1 & 0 & 0 \\
\hline $\begin{array}{c}\text { Auditori \& } \\
\text { Kinestetik }\end{array}$ & 1 & 1 & 3 & 1 & 0 \\
\hline $\begin{array}{c}\text { Visual \& } \\
\text { Kinestetik }\end{array}$ & 0 & 0 & 3 & 0 & 0 \\
\hline
\end{tabular}

Data pada Tabel 12 menunjukkan kajian antara tingkatan HOTS siswa ditinjau dari gaya belajar. Berdasarkan data tersebut dapat diketahui bahwa siswa yang memiliki gaya belajar auditori dan kinestetik cenderung memiliki tingkatan HOTS yang lebih beragam, sedangkan siswa dengan gaya belajar visual dan kinestetik memiliki tingkatan HOTS pada kategori sedang. Gambaran persentase kemampuan HOTS siswa jika ditinjau dari gaya belajarnya ditunjukkan pada Gambar 3.

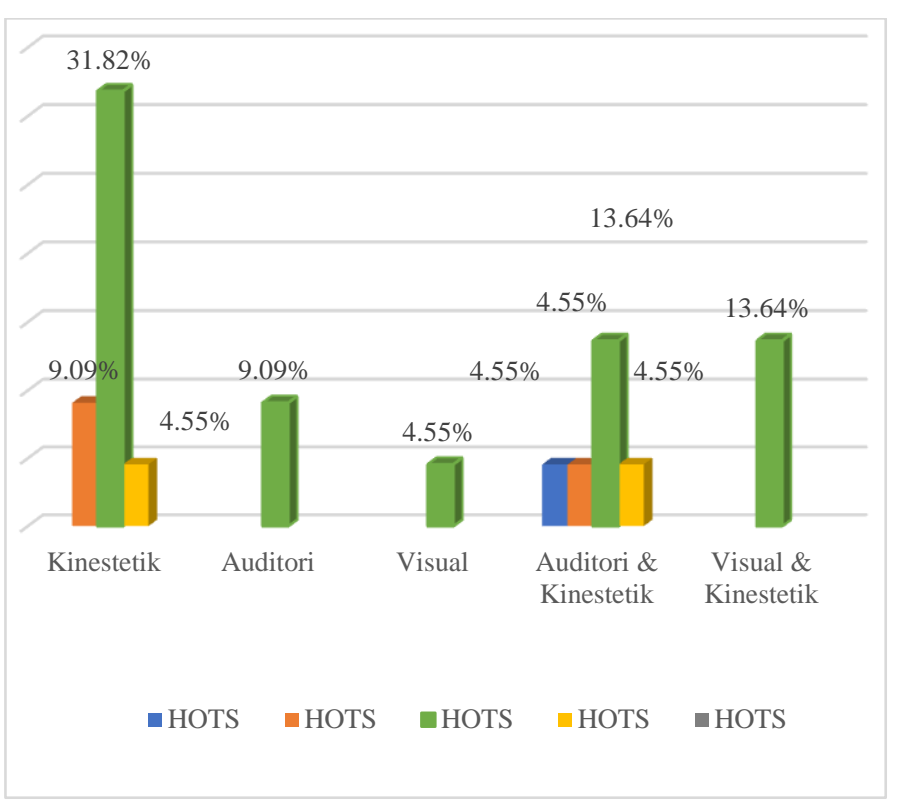

\section{Gambar 3. Tingkatan HOTS Ditinjau dari Gaya Belajar}

Hasil analisis data yang ditampilkan pada Tabel 12 dan Gambar 3 menunjukkan bahwa kecenderungan siswa berada pada gaya belajar kinestetik dan gabungan antara auditori dan kinestetik. Namun belum dapat ditemukan pola berarti terkati tingkatan HOTS siswa. Hal ini dikarenakan bahwa terdapat sebaran yang merata pada gaya belajar auditori dan kinestetik yang artinya masingmasing tingkatan HOTS diperoleh pada siswa dengan gaya belajar ini. Namun, apabila di telisik secara mendalam dapat dikaji bahwa tingkatan rata-rata HOTS siswa yang berada pada kategori sedang dan hampir semua siswa dengan semua tipe gaya belajar yang dikategorikan masuk pada tingkatan HOTS ini. Hal ini menunjukkan bahwa pola belajar siswa belum mendorong peningkatan HOTS secara maksimal. Sebagaimana ditunjukkan dalam hasil pengolahan data, sebaran terbanyak berada pada tingkat HOTS sedang masuk dalam sebaran terbanyak gaya belajar siswa. Hasil ini menunjukkan secara tidak langsung bahwa gaya belajar memiliki dampak terhadap kemampuan siswa yang dalam hal ini adalah kemampuan berpikir tingkat tinggi/ HOTS. Hasil ini sesuai dengan pendapat (Jampel, 2016) yang menyatakan bahwa gaya belajar merupakan faktor utama terhadap pencapaian siswa. Pendapat serupa juga diungkapkan oleh (Partingto et al., 2021) bahwa gaya belajar membuat siswa memiliki tingkatan HOTS yang berbeda. Hal ini menunjukkan bahwa ada keterkaitan antara gaya belajar terhadap pencapaian hasil belajar yang dalam hal ini dikategorikan sebagai HOTS. Gaya belajar dapat dikategorikan sebagai aktivitas belajar siswa yang dapat menjadi penentu dari capaian pembelajaran (Putri Ningrat dkk, 2018). 


\section{KESIMPULAN}

Kemampuan Higher Order Thinking Skills merupakan kemampuan berpikir yang penting untuk dikembangkangkan sejak dini. Hasil validasi terhadap asesmen HOTS yang dikembangkan berada pada kategori layak uji skala terbatas.

Karakteristik dari asesmen HOTS yang dikembangkan berdasarkan uji pakar, uji validitas, reliabilitas, daya beda, dan tingkat kesukaran soal menunjukkan hasil yang baik. Hasil dari uji pakar berada pada simpulan instrumen asesmen yang dikembangkan dapat digunakan dengan sedikit revisi dan rata-rata skor yang diperoleh adalah 3.38. Hasil uji validitas melalui SPSS menunjukkan bahwa 2 soal tidak valid dan 18 soal valid, sedangkan skor pada uji reliabilitas adalah 0.934 dengan kategori baik. Selanjutnya berdasarkan uji daya beda terdapat 2 butir soal dengan tingkat daya pembeda sangat baik, 10 butir soal kategori baik, 6 butir soal dengan kategori cukup, dan 2 butir soal dengan kategori jelek. Hasil uji tingkat kesukaran soal menunjukkan bahwa 8 soal tergolong dengan kategori mudah, 11 soal kategori sedang, dan 1 soal kategori sulit. Dari hasil tersebut dipilih 15 soal yang selanjutnya digunakan untuk mengukur tingkatan HOTS pada siswa.

Hasil pengukuran HOTS siswa menunjukkan bahwa 9.09\% siswa berada pada kategori rendah, $72.73 \%$ siswa berada pada kategori sedang, $13.64 \%$ siswa berada pada kategori tinggi, dan $4.55 \%$ siswa berada pada kategori sangat tinggi. Selain pengukuran HOTS juga diukur gaya belajar siswa untuk mengkaji bagaimana tingkatan HOTS dipandang dari gaya belajarnya. Hasil pengukuran tersebut menunjukkan bahwa terdapat 5 kategori gaya belajar siswa yakni kinestetik, auditori, visual, gabungan auditori dan kinestetik, serta gabungan visual dan kinestetik. Berdasarkan hasil pengolahan data, diketahui bahwa siswa yang memiliki gaya belajar auditori dan kinestetik memiliki tingkatan HOTS yang beragam. Hampir semua siswa yang memiliki gaya belajar sesuai kategori memiliki tingkatan HOTS sedang, ini menunjukkan bahwa guru dapat memaksimalkan pola pembelajaran dengan memperhatikan gaya belajar tiap siswa untuk peningkatan HOTS.

\section{SARAN}

Peneliti yang hendak mengambil topik serupa dapat melakukan penelitian dengan fokus mengukur pengaruh antara keduanya, sehingga dapat diketahui bagaimana kedudukan dari gaya belajar dalam meningkatkan HOTS pada siswa. Saran juga diberikan kepada guru, agar dapat memperhatikan gaya belajar siswa dalam pelaksanaan pembelajaran sehingga peningkatan HOTS dapat lebih efektif.

\section{DAFTAR PUSTAKA}

Ariesta, F. W. (2018). Mengintegrasikan Higher Order of Thingking Skill (HOTS) Pada Pembelajaran Sains di SD. Binus University | Pendidikan Guru Sekolah

Dasar. https://pgsd.binus.ac.id/2018/11/23/mengintegrasik an-higher-order-of-thinking-skill-hots-padapembelajaran-sains-di-sd/

Bagiyono. (2017). Analisis Tingkat Kesukaran dan Daya Pembeda Sial Ujian Pelatihan Radiografi Tingkat 1. Widyanuklida, 16(No. 1), 1-12. http://reponkm.batan.go.id/140/1/05_analisis_tingkat_kesuka ran.pdf

DIKDAS, G. (2019). Pentingnya Guru Menguasai HOTS. Http://Pgdikdas.Kemdikbud.Go.Id/ReadNews/Pentingnya-Guru-Menguasai-Hots. http://pgdikdas.kemdikbud.go.id/readnews/pentingnya-guru-menguasai-hots

Effendi, H., \& Hendriyani, Y. (2016). Pengembangan Model Blended Learning Interaktif Dengan Prosedur Borg and Gall. International Seminar On Education (ISE), 62-70.

Fitriani, D., Suryana, Y., \& Hamdu, G. (2018). Pengembangan Instrumen Tes Higher-Order Thinking Skill pada Pembelajaran Tematik Berbasis Outdoor Learning di Sekolah Dasar Kelas IV. Indonesian Journal of Primary Education, 2(1), 87. https://doi.org/10.17509/ijpe.v2i1.13752

Hanifah, N. (2019). Pengembangan instrumen penilaian Higher Order Thinking Skill ( HOTS ) di sekolah dasar. Conference Series, 1(1), 1-8. http://ejournal.upi.edu/index.php/crecs/article/view $/ 14286$

Intan, F. M., Kuntarto, E., \& Alirmansyah, A. (2020). Kemampuan Siswa dalam Mengerjakan Soal HOTS (Higher Order Thinking Skills) pada Pembelajaran Matematika di Kelas V Sekolah Dasar. JPDI (Jurnal Pendidikan Dasar Indonesia), 5(1), 6. https://doi.org/10.26737/jpdi.v5i1.1666

Jampel, I. N. (2016). Analisis Motivasi Dan Gaya Belajar Siswa Dalam Pembelajaran Di Sekolah Dasar. Jurnal Pendidikan Dan Pengajaran, 49(3), 109. https://doi.org/10.23887/jppundiksha.v49i3.9015

Kuswana, W. S. (2014). Taksonomi Kognitif Perkembangan Ragam Berpikir. PT remaja Rosdakarya.

Magdalena, I., Fauziah, S. N., Faziah, S. N., \& Nupus, F. S. (2021). Analisis Validitas, Reliabilitas, Tingkat Kesulitan dan Daya Beda Butir Soal Ujian Akhir Semester Tema 7 Kelas III SDN Karet 1 Sepatan. Bintang: Jurnal Pendidikan Dan Sains, 3(2), 198214.

https://ejournal.stitpn.ac.id/index.php/bintang/articl e/view/1291

Maimunah, M., Andrari, F. R., \& Qadarsih, N. D. (2020). Analisis Higher Order Thinking Skills (Hots) Calon Guru Matematika Ditinjau Dari Gaya Belajar. SAP (Susunan Artikel Pendidikan), 4(3), 237-244. https://doi.org/10.30998/sap.v4i3.6287

Majir, A. (2019). Blended Learning Dalam Pengembangan Pembelajaran Suatu Tuntutan Guna Memperoleh Keterampilan Abad Ke-21. Sebatik, 
23(2), 359-366. https://doi.org/10.46984/sebatik.v23i2.783

Ningrat, S. P., Tegeh, I. M., \& Sumantri, M. (2018). Kontribusi Gaya Belajar Dan Motivasi Belajar Terhadap Hasil Belajar Bahasa Indonesia. Jurnal Ilmiah Sekolah Dasar, 2(3), 257. https://doi.org/10.23887/jisd.v2i3.16140

Palobo, M., \& Tembang, Y. (2019). Analisis Kesulitan Guru Dalam Implementasi Kurikulum 2013 Di Kota Merauke. Sebatik, 23(2), 307-316. https://doi.org/10.46984/sebatik.v23i2.775

Partingto, W. A., Fathani, A. H., \& Walida, S. El. (2021). Analisis Kemampuan Siswa Menyelesaikan Soal Tipe HOTS (Higher Order Thingking Skill) Ditinjau Dari Gaya Belajar. Jurnal Penelitian, Pendidikan, Dan Pembelajaran, 16(1), 123-131.

Pramuaji, K. A., \& Loekmono, L. (2018). Uji Validitas Dan Reliabilitas Alat Ukur Penelitian: Questionnaire Empathy. Jurnal Ilmiah Bimbingan Konseling Undiksha, 9(2), 74-78.

Retnawati, H., Djidu, H., Kartianom, Apino, E., \& Anazifa, R. D. (2018). Teachers' knowledge about higher-order thinking skills and its learning strategy. Problems of Education in the 21st Century, 76(2), 215-230. https://doi.org/10.33225/pec/18.76.215

Santika, R. R., Ramadhan, K., Andri, M., Solehuddin, A., \& Juanita, S. (2019). Implementasi Game Edukasi Belajar Bahasa Inggris Dengan Metode
Game Development Life Cycle Dan Pendekatan Taksonomi Bloom. Sebatik, 23(2), 392-402. https://doi.org/10.46984/sebatik.v23i2.788

Sopiani, P. S., Said, I., \& Ratnawati. (2019). Investigating Students' Higher Order Thinking Skills (HOTS) in Writing Skill (A Case Study at the Eleventh Grade of a Senior High School in Banjar). Journal of Wind Engineering and Industrial Aerodynamics, 3(3), 328-342.

Sudjana, N. (2017). Penilaian Hasil Proses Belajar Mengajar. Remaja Rosdakarya.

Sundayana, R. (2016). Statistika Penelitian Pendidikan. Alfabeta.

Yani, A., Asri, A. F., \& Burhan, A. (2014). Distraktor Soal Ujian Semester Ganjil Mata Pelajaran Produktif Di Smk Negeri 1 Indralaya Utara. Jurnal Pendidikan Teknik Mesin, 1(2), 98-115.

Yusup, F. (2018). Uji Validitas dan Reliabilitas Instrumen Penelitian Kuantitatif. Jurnal Tarbiyah: Jurnal Ilmiah Kependidikan, 7(1), 17-23. https://doi.org/10.18592/tarbiyah.v7i1.2100

\section{UCAPAN TERIMA KASIH}

Terima kasih diucapkan kepada Institut Shanti Bhuana yang telah mendukung penelitian ini baik secara finansial dan non finansial sehingga penelitian ini dapat berjalan dengan baik. Terima kasih juga diberikan kepada SDN 9 Bengkayang yang telah menjadi tempat terlaksananya penelitian ini. 